\title{
Загоення різаних ран шкірних покривів під впливом нановмісних біодеградуючих ранових покриттів (експериментальне дослідження)
}

\begin{abstract}
Мета роботи: дослідити вплив нановмісних біодеградуючих ранових покриттів на загоєння неускладнених різаних ран шкірних покривів в експерименті in vivo.

Матеріали і методи. Дослідження проводили із застосуванням біодеградуючої полімерної плівки насиченої нанооксидом цинку та розчином гідратованого фулерену $\mathrm{C}_{60}$ та ранового покриття Curasorb Zn на 53 морських свинках у клініко-біологічній базі “Віварій” ДВНЗ “Івано-Франківський національний медичний університет” з дотриманням санітарно-гігієнічних норм та правил Європейської конвенції про захист хребетних тварин.

Термін спостереження - 3, 7, 4 та 21 доби. Виконували планіметричні, патоморфологічні та мікробіологічні дослідження.

Результати досліджень та їх обговорення. Морфологічно на третю добу у всіх дослідних групах спостерігали масивні ділянками некрозу, крововиливи та набряк субепітеліальних м’яких тканин.

Площа ранової поверхні у тварин II групи зменшилась на 17,8 \%, що є кращим результатом порівняно 3 I групою, а у тварин III групи площа рани до 3-ї доби зменшилась на 25,8 \%. Утворення грануляційної тканини на 7-му добу в III групі тварин відбувалося активніше, ніж у тварин II групи, що проявлялося більшою кількістю новоутворених капілярів та менш вираженою запальною інфільтрацією зони оперативного втручання.

На 14-ту добу експерименту в I дослідній групі площа ран становила $(148,9 \pm 8,5)$ мм² $^{2}$ що вказувало на зменшення площі на 70,4%. У ІІ групі на 14-ту добу площа ран зменшилась на 90,4%, а у III групі була повна епітелізація.
\end{abstract}

Ключові слова: різана рана; полімерні плівки; експеримент.

Постановка проблеми і аналіз останніх досліджень та публікацій. Найважливішим положенням вчення про рани є доведений факт спільності процесів загоєння ранового дефекту будьякої етіології та локалізації, що відображається фазністю перебігу ранового процесу - запалення, регенерація, епітелізація та реорганізація рубця $[1,2]$.

Загоєння ран є багатофакторним фізіологічним процесом. Крім клітинних і біохімічних компонентів, є інші фактори, які сприяють загоєнню тканин, серед них у сучасній науці описані різні біоматеріали, що впливають на згоєння пошкоджених тканин [3].

На сьогодні в медицині найчастіше застосовують та вивчають природні та синтетичні біодеградуючі полімери: білки (желатин, колаген, альбумін) полісахариди (хітозан, целюлоза), поліефіри та інші $[4,5]$.

Саме тому ми розробили біодеградуючі нановмісні полімерні плівки для лікування ран різного генезу, котрі вивчені в експерименті на тваринах.

Для достовірного вивчення процесу первинного та вторинного загоєння ран рановий процес відтворюють на моделях різаної рани в експерименті на тваринах. Така модель сприяє вивченню впливу досліджуваного засобу на швидкість загоєння ран, процес утворення грануляції та епітелізацію [6].
Мета роботи: дослідити вплив нановмісних біодеградуючих ранових покриттів на загоєння неускладнених різаних ран шкірних покривів в експерименті in vivo.

Матеріали і методи. Дослідження впливу біодеградуючих полімерних матеріалів на загоєння асептичних різаних ран шкірних покривів, що відбувається вторинним натягом, проводилось із застосуванням біодеградуючої полімерної плівки насиченої нанооксидом цинку (розмір частинок 30 нм (YURUI (SHANGHAI) CHEMICAL CO., LTD, CHINA) з концентрацією у плівці 5 \% та розчином гідратованого фулерену $\mathrm{C}_{60}$. Для порівняння застосовували нетканинне ранове покриття у вигляді пластинки із натуральних альгінатних волокон Curasorb ZN, які містять іони цинку.

Експериментальне дослідження проводили на 53 лабораторних тваринах, а саме морських свинках виду “Мурчаки” 3 середньою вагою $(354,2 \pm 14,2)$ г. Оперативні втручання виконували у клініко-біологічній базі “Віварій” ДВНЗ “ІваноФранківський національний медичний університет” з дотриманням санітарно-гігієнічних норм та правил Європейської конвенції про захист хребетних тварин (European convention for the protection of vertebrate animals used for experimental and other scientific purposes. - Counsil of Europe. - Strasburg, 1986), Закону України № 3447-IV “Про захист 
тварин від жорстокого поводження”, наказу МО3 України від 01.11.2000 р. № 281, загальних етичних принципів експериментів на тваринах, ухвалених Першим національним конгресом України 3 біоетики (2001). При проведенні експериментального дослідження дотримувалися вимог наказу Міністерства освіти і науки, молоді та спорту України від 01.03.2012 р. № 249 “Про затвердження порядку проведення науковими установами дослідів, експериментів на тваринах".

Усі тварини були здорові та знаходились у карантині 10 діб перед проведенням дослідження. Тварин розділяли на групи: I група - без лікування; II група - пластинки Curasorb Zn; III група - досліджувана біодеградуюча полімерна плівка з нанооксидом цинку та гідратованим фулереном $\mathrm{C}_{60}$.

Під загальним знеболенням оксибутирату нартію з розрахунку 0,15 мл на 100 г ваги з дотриманням усіх правил асептики та стерильності в операційній тварин фіксували у положенні на животі, обробляли заздалегіть депільовану міжлопаткову ділянку шкіри спини 5 \% спиртовим розчином йоду, обкладали операційне поле стерильним марлевим матеріалом та скальпелем розсікали шкіру завдовжки 50 мм. У тварин, у яких проводилось дослідження, загоєння ран вторинним натягом, заміряли площу рани та проводили мікробіологічне дослідження, а саму рану не ушивали.

Терміни спостереження становили 3, 7, 14 та 21 доба. Планіметричні дослідження проводили у 30 тварин за допомогою програми UTHSCSA ImageTool 2.0 з одночасним дослідженням мікробіологічної чистоти ран.

Патоморфологічне дослідження ран та навколишніх тканин проводили у 24 тварин, з яких 6 тварин були виведені з експерименту у терміні спостереження 21 доба, котрим проводили планіметричне дослідження, а 18 тварин виводили 3 експерименту в терміни 3, 7 та 14 діб.

Виведення тварин з експерименту здійснювали через евтаназію шляхом внутрішньочеревного введення розчину тіопенталу натрію у дозі 0,1 г згідно 3 рекомендаціями та етичними стандартами відповідно до Закону України від 21.02.2006 р. № 3447-1 "Про захист тварин від жорстокого поводження”.

Морфологічні дослідження проводили на базі кафедри патоморфології та судової медицини ДВНЗ “Івано-Франківський національний медичний університет”. Отриманий матеріал фіксували 48 год у 10 \% розчині нейтрального забуференого формаліну, а далі зневоднювали у висхідній батареї спиртів та здійснювали парафінову заливку. На санному мікротомі робили серійні гістологіч- ні зрізи завтовшки 5 мкм, а після депарафінізації зрізів препарати забарвлювали гематоксиліном та еозином і аналізували їх на мікроскопі Carl ZEISS Axiostar plus (Microlmaning, Німеччина), обладнаному фотокамерою Canon G 10 для отримання цифрових зображень.

Мікробіологічне дослідження проводили у Науково-дослідній лабораторії кафедри мікробіології ДВНЗ “Івано-Франківський національний медичний університет”. Матеріали для посіву забирали стерильним ватним тампоном із усієї поверхні рани. Підготовлений таким чином зразок висівали на кров'яний агар та середовище Ендо за методом Голда для виявлення та кількісного підрахунку числа життєздатних бактеріальних клітин.

Статистичну обробку проводили за допомогою спеціалізованого пакета аналізу медико-біологічних данних для програми Excel.

Результати досліджень та їх обговорення. Одразу після розрізу шкірних покривів вимірювали площу модельованих ран, що становила в середньому $\mathrm{S}=500,2 \pm 20,7 \mathrm{Mм}^{2}$.

Процес загоєння ран тварини I групи проходив повільно порівняно з тваринами II та III груп. Biзуально спостерігався виражений запальний процес країв рани та навколишніх тканин з активними серозними виділеннями у тварин I групи.

Морфологічно на третю добу після виведення тварин з експерименту у всіх досліджуваних групах спостерігали відсутність покривного епітелію, масивні ділянками некрозу, крововиливи та набряк субепітеліальних м'яких тканин.

Площа ранової поверхні у тварин II групи зменшилась на 17,8 \%, що є кращим результатом порівняно з I групою, а у тварин III групи площа рани до 3-ї доби зменшилась на 25,8 \%, що є найкращим результатом. У тварин II та III груп запальна реакція навколишніх тканин та країв ран була менш виражена, а ексудація не така значна.

До 7-ї доби у тварин III групи були практично відсутні виділення з ран та макроскопічно спостерігали утворення грануляцій. Морфологічно розростання грануляційної тканини з утворенням капілярів, проліферацією фібробластів і сполучнотканинних волокон на фоні набряку та вогнищевих крововиливів, вогнищева, переважно периваскулярна, інфільтрація гістіоцитами та еозинофільними лейкоцитами. Утворення грануляційної тканини в III групі тварин відбувалося активніше, ніж у тварин II групи, що проявлялося збільшенням кількості новоутворених капілярів та менш вираженою запальною інфільтрацією зони оперативного втручання. 
Площа ран зменшилась в середньому на 46,9 \% у даній групі та на 42,7 \% у групі III, що значно перевищило показник 23,9 \% у I групі. Окрім вищеописаних змін, у тварин II групи спостерігали виражений набряк м'язового шару дерми та вогнищеву запальну інфільтрацію поліморфноядерними лейкоцитами як поверхневих, так і глибоких зон оперативного втручання.

У тварин I групи на момент перев'язки марлева серветка щільно фіксувалася до країв рани, що спричиняло больові відчуття у тварин. Морфологічно у цій групі тварин спостерігали зменшення площі некротизованих тканин із вогнищевою запальною інфільтрацією новоутворених волокон молодої сполучної тканини, вираженим набряком та дистрофічними змінами м'язових клітин. В грануляційній тканині більшості виведених з експерименту тварин спостерігали лише поодинокі капіляри, що пояснює більш тривалий перехід фаз загоєння рани порівняно з дослідними групами в зв'язку з явищами гіпоксії ділянки оперативного втручання.

На 14 добу експерименту в I дослідній групі площа ран становила $(148,9 \pm 8,5)$ мм² $^{2}$ що вказувало на зменшення площі на 70,4 \% відносно початкової площі ран. Макроскопічно спостерігали вогнищеву епітелізацію ранової поверхні з дрібними ділянками лімфоцитарної запальної інфільтрації, крововиливами та вираженим набряком власне дерми.

У II групі на 14-ту добу площа ран зменшилась на 90,4 \%, спостерігали явища гіперрегенерації хірургічної рани у вигляді гіпертрофії покривного епітелію з його вираженим акантозом та ділянками гіперкератозу. Окремі клітини епідермісу були в стані дистрофії та апоптозу.

У III групі тварин на 14-ту добу виведення 3 експерименту спостерігали повну епітелізацію ранової поверхні з утворенням грубоволокнистого сполучнотканинного рубця, що поширюється від епідермісу до м’язового шару дерми без відновлення волосяних фолікулів (табл.).

Повна епітелізація і закриття вільної ранової поверхні відбулись у тварин I групи на 20 добу, у тварин II групи - на 16 добу, а у тварин III групи - на 14 добу.
Отримані нами попередні результати застосування полімерних матеріалів на моделі різаної рани, загоєння котрої проходить первинним натягом, та викладені результати у даній роботі загоєння ран вторинним натягом свідчать про доцільність та правильність застосування такого комплексного підходу до вивчення лікування ран шкірних покривів за допомогою полімерних матеріалів. Отримані результати вивчення впливу полімерів на загоєння ран первинним натягом показали ефективність застосування біодеградуючого полімеру 3 комплексною захисною та регенеративною стимулюючою дією. Запропонований нами наступний етап дослідження підтвердив дані результати та показав високу ефективність використання такого біодеградуючого полімерного матеріалу порівняно $з$ відомим матеріалом для за живлення ран. Застосування оксиду цинку з нанорозмірами частинок забезпечило високу надійність профілактики потрапляння патогенних мікроорганізмів у рану та виникнення інфекційних ускладнень.

Краще загоєння ран при застосуванні плівок, насичених гідратованим фулереном $\mathrm{C}_{60}$ пояснюють властивості даного засобу, а саме протекторна, протизапальна та регенеративна з можливість специфічного захисту від негативного впливу на ДНК, захист тканини від ультафіолетового опромінення і радіопротекторна дії, противірусні, антиоксидантні, імуностимулюючі та протипухлинні властивості $[7,8]$. Високі репаративні властивості композицій фулерену $\mathrm{C}_{60}$ описані в сучасних джерелах літератури та дають можливість говорити про перспективи його застосування при місцевому лікуванні ран [9, 10].

Результати експериментального дослідження свідчать, що розроблені нами біодеградуючі полімерні матеріали відповідають сучасним вимогам до покрівельних матеріалів при місцевому лікуванні ран, володіють комплесними сорбційним, паропропускними, вологопроникними та біодеградуючими властивостями, мають виражену антебактеріальну, протизапальну, регенеративну дію. Саме такі властивості забезпечують умови ефективного загоєння ран, зменшення їх розмірів,

Таблиця. Площа ранової поверхні в різні терміни спостереження при загоєнні вторинним натягом

\begin{tabular}{|c|c|c|c|c|c||}
\hline \multirow{2}{*}{ Групи } & \multicolumn{5}{|c||}{ Терміни спостереження, доба } \\
\cline { 2 - 6 } & 0 & 3 & 7 & 14 & 21 \\
\cline { 2 - 6 } & \multicolumn{5}{|c||}{ площа S, мм ${ }^{2}$} \\
\hline I & $503,2 \pm 17,4$ & $455,4 \pm 13,6$ & $355,9 \pm 21,7$ & $148,9 \pm 8,5$ & повне загоєння \\
\hline II & $499,8 \pm 21,9$ & $411 \pm 28,1$ & $286,2 \pm 16,5$ & $48 \pm 7,7$ & повне загоєння \\
\hline III & $497,5 \pm 24$ & $368,9 \pm 12,8$ & $264,2 \pm 9,8$ & $14,6 \pm 2,5$ & повне загоєння \\
\hline \hline
\end{tabular}


утворення грануляцій та пришвидшує епітелізацію. Зменшення площі ран на третю добу можна пояснити поєднаним ефектом за рахунок вираженого сорбційного ефекту полімеру та скороченням шкірних покривів як реакції на їх пошкодження. Пік дії плівки припадає у період до 7-10 доби, оскільки в період другої фази рідина рани забезпечує можливість біодеградації плівки, а еластичність полімерного матеріалу сприяє контакту по усій поверхні рани та виділенню діючої речовини в уражену ділянку. Плівки створюють придатне для загоєння вологе середовище, а наявність нанооксиду цинку запобігає інфікуванню.

Висновки. 1. Розроблені полімерні плівки проявляють ранозагоювальні властивостями у I та II фазі ранового процесу на відміну від групи порівняння.

\section{СПИСОК ЛІТЕРАТУРИ}

1. Boyko T. V. Review of the current management of pressure ulcers / T. V. Boyko, M. T. Longaker, G. P. Yang // Adv. Wound Care (New Rochelle). - 2018. - Vol. 7 (2). - P. 57-67. doi: 10.1089/wound.2016.0697

2. The cellular, biochemical, and mechanical phases of wound healing / R. E. Pollock, F. C. Brunicardi, D. K. Andersen [et al.] // Schwartz's Principles of Surgery, Ninth Edition. - 2009. McGraw-Hill Professional.

3. Mir M. M. Synthetic polymeric biomaterials for wound healing: a review / M. M. Mir, N. Ali // Prog. Biomater. - 2018. - Vol. 7 (1). - P. 1-21.

4. Григорьева М. В. Полимерные системы с контролируемым высвобождением биологически активных соединений / М. В. Григорьева // Биотехнология. - 2011. -№ 4(2). - С. 9-19. 5. Barrier, structural and mechanical properties of bovine gelatin-chitosan blend films related to biopolymer interactions / N. Benbettaieb, M. Kurek, S. Bornaz, F. Dbeaufort // J. Sci. Food Agriculture. - 2014. - Vol. 84 (12). - P. 2409-2419.

\section{REFERENCES}

1. Boyko, T.V., Longaker, M.T., \& Yang, G.P. (2018). Review of the current management of pressure ulcers. Adv. Wound Care (New Rochelle), 7 (2), 57-67. doi: 10.1089/wound.2016.0697 2. Pollock, R.E., Brunicardi, F.C., Andersen, D.K. (2009). The cellular, biochemical, and mechanical phases of wound healing. Schwartz's Principles of Surgery. Ninth Edition. McGraw-Hill Professional.

3. Mir, M.M., \& Ali, N. (2018). Synthetic polymeric biomaterials for wound healing: a review. Prog. Biomater., 7 (1), 1-21.

4. Grigoreva, M.V. (2011). Polimernye sistemy s kontroliruemym vysvobozhdeniem biologicheski aktivnykh soedineniy [Polymer systems with controlled release of biologically active compounds]. Biotekhnologiya - Biotechnology, 4 (2), 9-19 [in Russian].

5. Benbettaieb, N., Kurek, M., Bornaz, S., \& Dbeaufort, F. (2014). Barrier, structural and mechanical properties of bovine gelatinchitosan blend films related to biopolymer interactions. J. Sci. Food Agriculture, 84 (12), 2409-2419.
Нановмісні полімерні плівки відповідають сучасним вимогам щодо ранових покриттів для загоєння ран: вони еластичні, поступово деградують та виділяють діючі речовини на ділянку ураження.

Досліджувані нановмісні біодеградуючі полімерні плівки - ефективний засіб лікування та профілактики інфікування ран та потребують подальшого комплексного експериментального дослідження.

Перспективи подальших досліджень. Враховуючи складність та невирішеність проблеми загоєння ран шкірних покривів, необхідно проводити подальший пошук оптимальних методів лікування ран з застосуванням сучасних нановмісних біодеградуючих технологій місцевої дії і дозованою доставкою лікарського засобу в ділянку ураження.

6. Екпериментальне вивчення нових препаратів для місцевого лікування ран : мет. реком. / Л. В. Яковлєва, О. В. Ткачова, Я. О. Бутко, Ю. Б. Лар’яновська. - Харків, 2013. - 52 с.

7. Агрегатное состояние с 60-фуллерена в различных середах / И. И. Гринюк, С. В. Прилуцкая, Н. С. Слободяник [и др.] // Biotechnologia Acta. - 2013. - № 672 (6). - С. 71-76.

8. Фулерени: перспективи практичного застосування в медицині, біології та екології / Д. В. Щур, 3. А. Матисіна, С. Ю. Загинайченко [и др.] // Вісник Дніпропетровського університету. Біологія. Екологія, - 2012. - 20(1). - С. 139-145.

9. Zongshun Lu. Photodynamic therapy with a cationic functionalized fullerene rescues mice from fatal wound infections / Lu Zongshun, Dai Tianhong, Huang Liyi [et al.] // Nanomedicine (Lond). - 2010. - Vol. 5 (10). - P.1525-1533. doi: 10.2217/nnm.10.98.

10. Anti-inflammatory effect of fullerene C60 in a mice model of atopic dermatitis / N. Shershakova, E. Baraboshkina, S. Andreev [et al.] // J. Nanobiotechnology. - 2016. - No. 14 (8). - P. 2-11. Published online 2016 Jan 25. doi: 10.1186/s12951-016-0159-z.

6. Yakovlieva, L.V., Tkachova, O.V., Butko, Ya.O., \& Larianovska, Yu.B. (2013). Metodychni rekomendatsii "Ekperymentalne vyvchennia novykh preparativ dlia mistsevoho likuvannia ran" [Methodical recommendations "Experimental study of new drugs for local wound healing"]. Kharkiv [in Ukrainian].

7. Grinyuk, I.I., Prilutskaya, S.V., \& Slobodyanik, N.S. (2013). Agregatnoe sostoyanie s60-fullerena v razlichnykh seredakh [The aggregate state of c60-fullerene in different environments]. Biotechnologia Acta, 672 (6), 71-76 [in Russian].

8. Shchur, D.V., Matysina, Z.A., \& Zahynaichenko, S.Yu. (2012). Fulereny: perspektyvy praktychnoho zastosuvannia v medytsyni, biolohii ta ekolohii [Fullerenes: prospects of practical application in medicine, biology and ecology.]. Visnyk Dnipropetrovskoho universytetu. Biolohiia. Ekolohiia - Bulletin of Dnipropetrovsk University. Biology. Ecology, 20 (1), 139-145 [in Ukrainian].

9. Zongshun Lu, Dai Tianhong, \& Huang Liyi (2010). Photodynamic therapy with a cationic functionalized fullerene 
rescues mice from fatal wound infections. Nanomedicine (Lond), 5 (10), 1525-1533. doi: 10.2217/nnm.10.98.

10. Shershakova, N., Baraboshkina, E., \& Andreev, S. (2016).
Anti-inflammatory effect of fullerene C60 in a mice model of atopic dermatitis. J. Nanobiotechnology, 14 (8), 2-11. doi: 10.1186/s12951-016-0159-z.

Електронна адреса для листування: popadyukoleg@ukr.net

\author{
O. Y. POPADYUK
}

Ivano-Frankivsk National Medical University

\title{
HEALING OF THE CUT WOUNDS OF THE SKIN UNDER THE INFLUENCE OF NANOMATERIALS OF BIODEGRADABLE WOUND HEALING (EXPERIMENTAL STUDY)
}

The aim of the work: to investigate the effect of nano-containing biodegradable wound on the healing of uncomplicated cutaneous wounds of the skin in the in vivo experiment.

Materials and Methods. The study was carried out using a biodegradable polymer film zinc-saturated polymer and hydrated fullerene $\mathrm{C}_{60}$ solution and Curasorb Zn wound dressing on 53 guinea pigs at the clinic-biological base "Vivarii" of the Ivano-Frankivsk National Medical University, in compliance with the sanitary and hygienic norms and rules of the European Convention on the Protection of Vertebrate Animals.

The observation dates were 3, 7, 14 and 21 days. Performed planimetric, pathomorphological and microbiological.

Results and Discussion. Morphologically, for the third day in all studied groups, massive sites of necrosis, hemorrhage and edema of subepithelial soft tissues were observed.

The area of the wound surface in animals of the group II decreased by $17.8 \%$, which is the best result compared with group I, and in animals of the group III the area of the wound before the 3rd day decreased by $25.8 \%$. The formation of granulation tissue in the 7th day in the group III of animals was more active than in animals of the group II, which was manifested by a greater number of newly formed capillaries and less severe inflammatory infiltration of the surgical intervention zone.

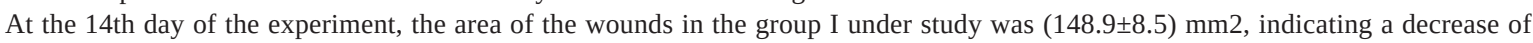
the area by $70.4 \%$. In the group II at the 14 th day, the area of wounds decreased by $90.4 \%$, and in group III there was complete epithelization.

Key words: cutaneous wound; polymer films; experiment.

\section{О. Я. ПОПАДЮК}

ГВУЗ “Ивано-Франковский национальный медицинский университет”

\section{ЗАЖИВ.ЛЕИЕ РЕЗАНЫХ РАН КОЖНЫХ ПОКРОВОВ ПОД ВЛИЯНИЕМ НАНОСОДЕРЖАЩИХ БИОДЕГРАДИРУЕМЫХ РАНЕВЫХ ПОКРЫТИЙ (ЭКСПЕРИМЕНТАЛЬНОЕ ИСС.ЕДОВАНИЕ)}

Цель работы: исследовать влияние наносодержащих биодеградируемых раневых покрытий на заживление неосложненных резаных ран кожных покровов в эксперименте in vivo.

Материалы и методы. Исследование проводилось с применением биодеградируемой полимерной пленки насыщенной нанооксидом цинка и раствором гидратированного фуллерена $\mathrm{C}_{60}$ и раневого покрытия Curasorb Zn на 53 морских свинках в клинико-биологической базе “Виварий” ГВУЗ “Ивано-Франковский национальный медицинский университет” из соблюдением санитарно-гигиенических норм и правил Европейской конвенции о защите позвоночных животных.

Сроки наблюдения составили 3, 7, 14 и 21 сутки. Выполняли планиметрические, патоморфологические и микробиологические исследования.

Результаты исследований и их обсуждение. Морфологически на третьи сутки во всех исследуемых группах наблюдали массивные участки некроза, кровоизлияния и отек субэпителиальных мягких тканей.

Площадь раневой поверхности у животных II группы уменьшилась на 17,8 \%, что является лучшим результатом по сравнению с I группой, а у животных III группы площадь раны до 3-х суток уменьшилась на 25,8 \%. Образование грануляционной ткани на 7-е сутки в III группы животных происходило активнее, чем у животных II группы, что проявлялось большим количеством вновь образованных капилляров и менее выраженной воспалительной инфильтрацией зоны оперативного вмешательства.

На 14 сутки эксперимента в I исследуемой группе площадь ран составляла $(148,9 \pm 8,5)$ мм²$^{2}$, что указывало на уменьшение площади на 70,4%. Во II группе на 14-е сутки площадь ран уменьшилась на 90,4 \%, а в III группе была полная эпителизация.

Ключевые слова: резанная рана; полимерные пленки; эксперимент. 